\title{
Collective Action for Small-Scale Producers of Agricultural Biodiversity Products
}

\author{
Froukje Kruijssen, Bioversity International \\ Menno Keizer, VECO, and \\ Alessandra Giuliani, Bioversity International
}

\author{
Research Workshop on Collective Action and Market Access for Smallholders \\ October 2-5, 2006 - Cali, Colombia
}

The CGIAR Systemwide Program on Collective Action and Property Rights (CAPRi) is an initiative of the 15 centers that belong to the Consultative Group on International Agricultural Research. The initiative promotes comparative research on the role played by property rights and collective action institutions in shaping the efficiency, sustainability, and equity of natural resource systems. CAPRi's Secretariat is hosted by the International Food Policy Research Institute's (IFPRI) Environment and Production Technology Division (www.ifpri.org).

CAPRi Working Papers contain preliminary material and research results and are circulated prior to a full peer review in order to stimulate discussion and critical comment. It is expected that most Working Papers will eventually be published in some other form, and that their content may also be revised. http://dx.doi.org/10.2499/CAPRiWP71

Copyright $\odot$ August 2007. International Food Policy Research Institute. All rights reserved. Sections of this material may be reproduced for personal and not-for-profit use without the express written permission of but with acknowledgment to IFPRI. To reproduce the material contained herein for profit or commercial use requires express written permission. To obtain permission to reprint, contact the IFPRI Communications Division at ifpri-copyright@cgiar.org.

CGIAR Systemwide Program on Collective Action and Property Rights (CAPRi) C/O INTERNATIONAL FOOD POLICY RESEARCH INSTITUTE

2033 K Street NW, Washington, DC 20006-1002 USA • T +1 202.862.5600 • F +1 202.467.4439 • www.capri.cgiar.org 


\section{ACKNOWLEDGEMENTS}

The authors wish to express their sincere gratitude to all farmers and collectors, other stakeholders and national partners that have provided us with information or supported the collection of data for the case studies. In particular authors would like to thank Dr. Sudha Mysore of the Indian Institute of Horticultural Research in Bangalore, India and Dr. S. Somsri of the Department of Agriculture in Bangkok, Thailand for their contributions to the tropical fruit case studies and Nguyen Thi Le Thuy, the director of the Dong Go Research Station of the Oil Plant Institute of Vietnam for the coconut fibre case, and the officers of the Syrian Ministry of Agriculture and Agrarian Reform and professors from the University of Aleppo for the cases conducted in Syria. We are also very grateful

for the comments of two anonymous reviewers. Any remaining inaccuracies in this paper can only be attributed to the authors. 


\begin{abstract}
The role of well-functioning markets for development is now widely recognized, however the challenge remains to make these markets benefit the poor and the environment. Increasing attention is being given to the potential role markets can play for agrobiodiversity conservation through product diversification and increasing competitiveness in niche and novelty markets. Bioversity International has undertaken several studies that explore the use of market-based approaches to on-farm agrobiodiversity management and livelihood improvement. Case studies have been developed on a range of species, varieties and derived products, including underutilized species and commodities in several regions of the world.

This paper explores how the theory of collective action can provide a more synthetic understanding of how market chains operate and how changes in the market chain and market institutions can permit a more equitable distribution of welfare benefits. The case studies illustrate the need for improved trust, a mutual understanding of each actor's involvement and the need for an agreed process of collective action that involves a high level of community participation to achieve an improved market chain organization benefiting the poor.

The cases differ in their degree of collective action, the level of market organization and the ways in which handling, processing, and innovative marketing add value to the agrobiodiversity products. Comparative analysis of these cases identified a range of options and situations in which market development can support agrobiodiversity conservation and livelihoods. Bringing together these experiences will also help to identify the situations in which a collective approach can maximize the capturing of market benefits for smallholders. Trade-offs between income generation, livelihood security, and agrobiodiversity conservation should be further examined in order to find solutions that support sustainable development of poor communities that manage agricultural biodiversity.
\end{abstract}

Keywords: agricultural biodiversity, market chain, market access, livelihoods, collective action 


\section{TABLE OF CONTENTS}

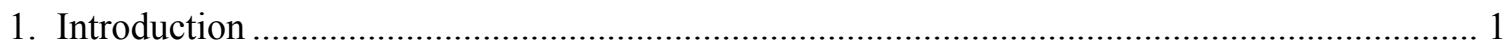

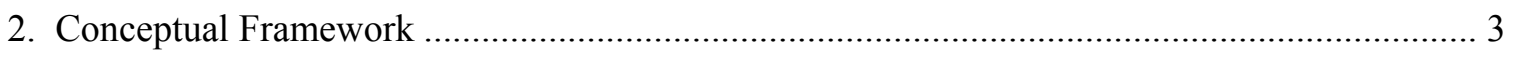

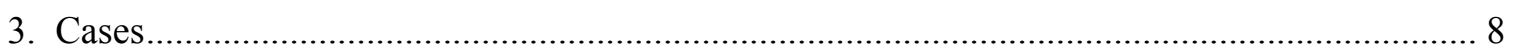

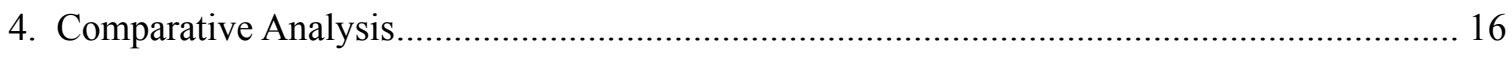

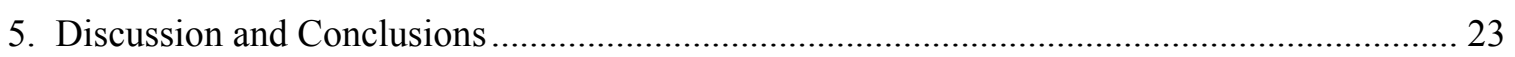

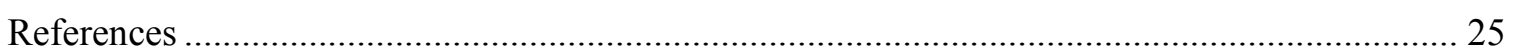




\title{
Collective Action for Small-Scale Producers of Agricultural Biodiversity Products
}

\author{
Froukje Kruijssen, ${ }^{1}$ Menno Keizer, ${ }^{2}$ and Alessandra Giuliani ${ }^{3}$
}

\section{INTRODUCTION}

Agricultural biodiversity provides livelihood support and contributes to resilient agro ecosystems worldwide. The value of biodiversity is found in both the public and private domain and can therefore be considered an "impure public good" (Smale 2004). This classification stems from the extent of rivalry in use and the difficulty of excluding users. Public interventions are therefore needed to ensure that the good is allocated in the required quantity. In order to ensure that public resources are spent in the most cost-effective manner, on-farm agrobiodiversity policies need to be targeted carefully. Public investment costs for on-farm agrobiodiversity management are considered to be lowest "... where both the public value of the resources is believed to be greatest ... and where the private net benefits farmers earn (monetary and non-monetary) through maintaining diverse crop genetic resources is high" (Smale 2004). Increasing farmer utility for a certain variety or species with a high public value will also enhance the incentive for farmers to maintain agrobiodiversity (including crop genetic resources) on farm. A method to increase the private value (and thus farmer utility) for agrobiodiversity is to enhance the income generated from these resources. In Figure 1 this is illustrated by the upwards arrow in the right side of the graph. The establishment of markets and improvement of access to markets for products derived from agrobiodiversity is considered to be a potentially successful tool to achieve this (Rietbergen et al. 2002).

\footnotetext{
${ }^{1}$ Froukje Kruijssen, Associate scientist, Bioversity International, Regional Office for Asia, the Pacific and Oceania PO Box 236, UPM Post office; 43400 Serdang, Selangor Darul Ehsan, Malaysia (f..kruijssen@cgiar.org )

${ }^{2}$ Menno Keizer, Regional marketing advisor East-Africa, VECO. P.O. Box 7844, Kampala, Uganda. (menno.keizer@veco-uganda.org)

${ }^{3}$ Alessandra Giuliani, Research fellow, Bioversity International, Hohgantweg 5, 3012 Bern-CH, Switzerland (Giuliani.ale@gmail.com)
} 
Figure 1- Increasing farmer utility for on-farm conservation. Adapted from Smale 2004

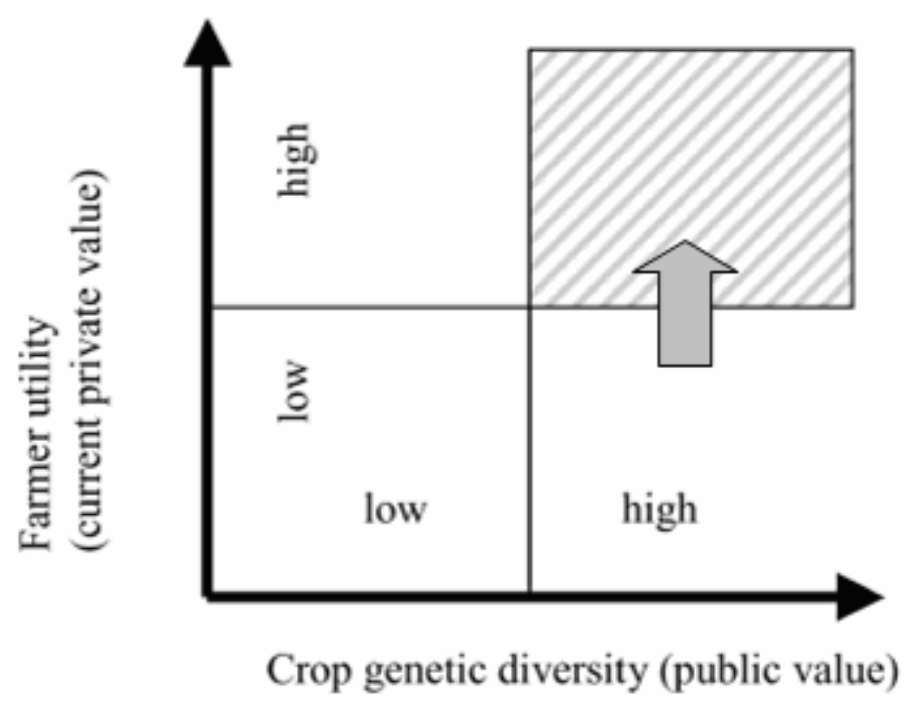

Individual smallholders in developing countries however face numerous constraints in the marketing of their products resulting from high transaction costs in the market chain. Firstly, they have limited access to physical and financial resources. This restricts their opportunities to increase their scale of production in order to reduce transaction costs and to invest in efficiency increasing and value adding technologies, but also creates a problem of scale for effective marketing of their product, as they lack resources for transport and handling and for fixed investments. In some cases labor limitations, which can often be solved by introducing a relatively simple technology, prevent farmers from embarking on otherwise attractive value adding activities. Secondly, smallholders have limited technical skills, no access to training on production and processing, and no access to information on market requirements. Lastly, individual farmers lack bargaining power and as a result there is no equal distribution of value added among the actors in the market chain, especially in the case of seasonal and highly perishable agricultural products.

Contract farming is often described as an effective means to solve most of the above mentioned problems. However, evidence seems to suggest that this excludes the smallest and poorest farmers because of high transaction costs involved in settling a contract (Marshall et al. 2006). This problem could be overcome by the formation of community-based organizations, whereby smallholders are able to pool their resources and market their products collectively, hence overcoming transaction costs resulting from their small size. It can improve their access to resources such as 
inputs, credit, training, transport and information, increase bargaining power (Bosc et al. 2002), and facilitate certification and labeling. In the context of long-term investments such as required for perennial crops and capital intensive processing technologies, a collective can also reduce individual farmer risk (Di Gregorio et al. 2004).

This paper considers five case studies that explore the use of market-based approaches to onfarm biodiversity management and livelihood improvement based on collective action. The aim of the paper is to compare these cases and evaluate them in terms of the level of collective action involved and the impact on on-farm biodiversity management. The cases presented in this paper include market chain analyses of Garcinia species in India and Thailand, coconut fiber in Vietnam, and laurel and capers in Syria. These cases were selected because the products are considered to be derived from local agrobiodiversity. Four cases deal with products that originate from so-called underutilized plant species (cowa, kokum, laurel and caper), which means that they are locally abundant but globally rare and currently have limited use in comparison to their economic potential (Gruère et al. 2006). The fifth case gives an example of a specific (and alternative) product derived from a particular local use of a commodity (in this case using the fiber instead of the nut for copra).

The remainder of this paper is organized as follows: Section 2 presents the conceptual framework that is applied to analyze the case studies. Section 3 gives an overview of the case studies and their key findings. Section 4 compares the cases in terms of the governance, level and effectiveness of collective action for increased access to the market of resource poor farmers and onfarm agrobiodiversity management. Section 5 presents some conclusions.

\section{CONCEPTUAL FRAMEWORK}

This paper will analyze above mentioned cases in terms of the role that collective action played in linking farmers to the market and conserving biodiversity on-farm. To do so requires a conceptual framework to identify the commonalities and differences. Figure 2 gives a schematic overview of this framework, depicts the process that should lead to collective action and presents outcomes and threats that may result from a collective action. We explain this framework, starting from the right-hand-side of the diagram below the dotted line. 
Figure 2. The process of collective action for smallholder market participation

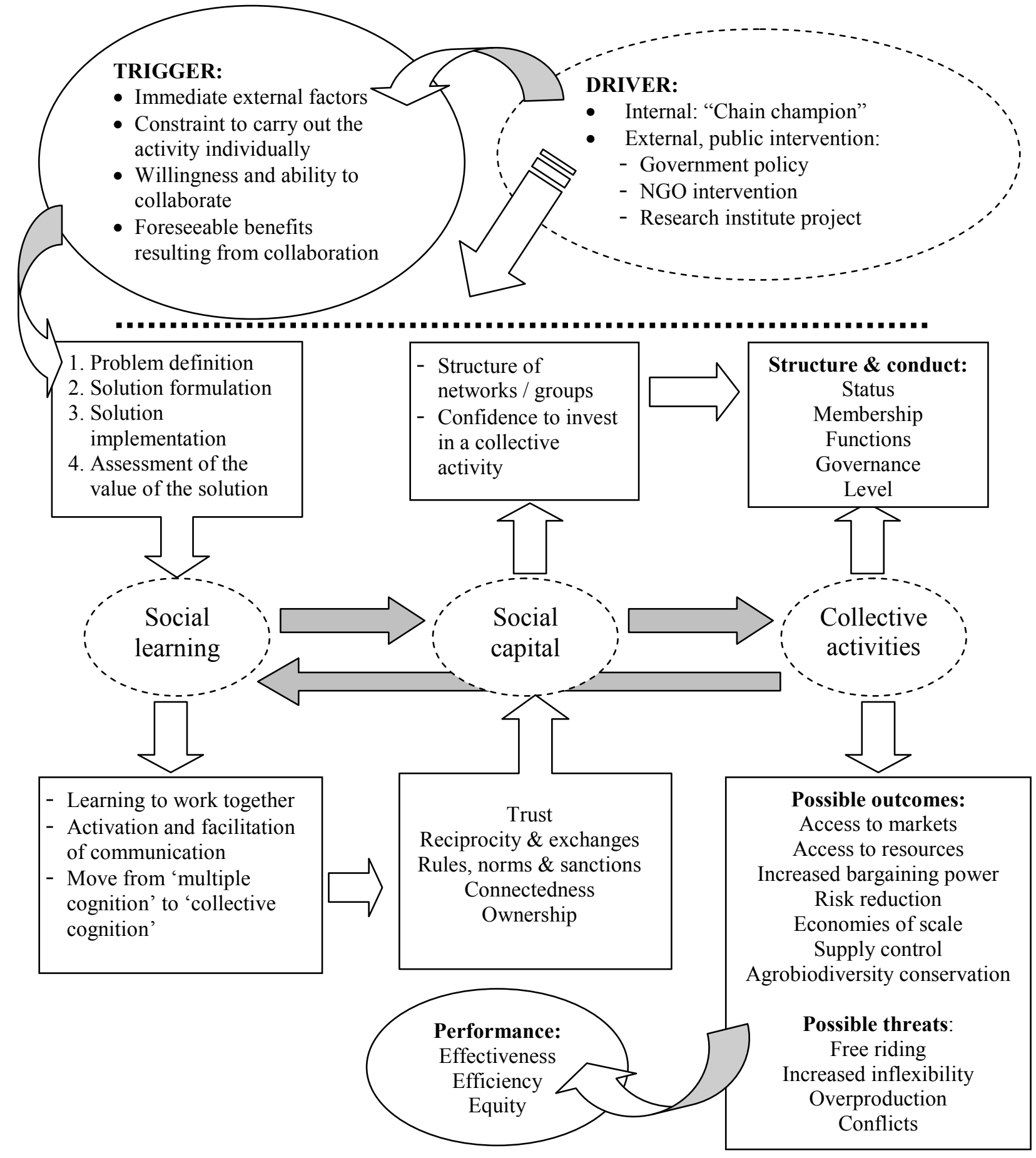


We define collective action as the coordinated behavior of groups toward a common interest or purpose (Vermillion 2001). In the context of the formation of groups that form the basis of collective action, literature often refers to the concept of social capital (Coleman 1988; Uphoff 1995; Koelen and Das 2002). This is described by Coleman $(1988 ; 1990)$ as 'the structure of relations between actors and among actors' that encourages productive activities. Hence, social capital facilitates cooperation as is shown in the diagram. People have the confidence to invest in collective activities, knowing that others will also do so. Johnson et al. (2002) state that where markets fail and transactions costs are high, social capital can make a significant contribution to firm performance by providing access to information and reducing the costs of contracting and coordination. Individuals and groups who can work collaboratively, and establish and maintain both trust-based relationships and networks of contacts will have an advantage over their competitors who are unable to work together (Johnson et al. 2002).

Pretty and Ward (2001) have identified four central aspects in the formation of social capital, i.e. (i) relations of trust; (ii) reciprocity and exchanges; (iii) common rules, norms and sanctions; (iv) connectedness, networks and groups. Koelen and Das (2002) describe that the basis for the exchanges between the actors in a collective activity is formed by a process that is referred to as 'social learning', which is "the process through which groups of people (or stakeholders) learn: together they define problems, search for and implement solutions, and assess the value of a solution for a specific practice." This process entails the shift from what the authors refer to as 'multiple cognition' to 'collective cognition'. This means that the individuals in the collective move from being totally different cognitive agents and having multiple perspectives to a group with shared attributes such as theories, values and collective action (Koelen and Das 2002). The concept also entails that these individuals reach insights that none could have reached alone, and that cannot be traced back to one particular individual's contribution (Giere 2002). To benefit from collective cognition, it is important that convergence to a shared idea of how to improve the situation and organize a useful knowledge network should occur only after dialogue between divergent viewpoints. The social-learning processes are seen as the engine of collective cognition and of improvements in and between professional practices (Jordan et al. 2003). The interaction that takes place during a collective activity also feeds back into the social learning process and will change the nature of social capital over time.

The initiation of the process of social learning and collective action is caused by a trigger. This can be found in many external factors usually beyond the control of the individual smallholder, ranging from natural disasters to price declines, and increased competition. However, there should be a constraint to carry out the activity individually and there should be a willingness to undertake it as a 
group demonstrated by a certain level of interconnectedness, motivation, and capacity (McCarthy 2004). Also the possible benefits to be reaped from collective action should be visible to participants. The forces that then drive the process to continue, the catalyst, can either be external in the form of public sector agencies such as government, NGOs or research institutes, or internal which is often a so-called "chain-champion," a farmer or other market chain actor that takes a leading role. The driver can also play a role in bringing together the possible collaborators and establishing the existence of pre-conditions such as the willingness to work together.

In order to design policies that are effective and sustainable it is important to understand the process of social learning and to ensure that this is undertaken through a participatory process involving the stakeholders and providing them with 'ownership' of the problems and solutions. This will greatly enhance the sustainability of a collective activity (van der Fliert et al. 2002; Campilan 2002). For the same reason we should also analyze which forms of collective action are most effective in terms of their outcomes for market participation and biodiversity conservation. A set of indicators is needed that assesses both the organizational aspects that have been instrumental for the outcomes, and evaluates the impact on market participation. For this purpose we examine the "structure-conduct-performance" (S-C-P) analysis commonly used in market chain analyses (for example Schmalensee 1989; Jabbar, Tambi and Mullins 1997; and Sexton 2000). Although this method is designed to analyze an entire market chain we will exclusively use it for the analysis of the outcome: market participation of the collective.

The term 'structure' in the S-C-P analysis refers to the environment in which institutions and agents operate in the market chain such as the number of buyers and sellers in a chain. The 'conduct' of a market chain deals with the coordination between the actors and how these are interrelated (Keizer 2003). In order to apply these concepts to collective action we draw on The Tuan et al. (2006) by describing the collective activities according to the following five characteristics: (i) status (e.g. association, history, network, cluster); (ii) membership (e.g. number, size and activities of members); (iii) functions (e.g. economic, social, political); (iv) governance (e.g. selection of members, selective incentives, sanctions, hierarchical vs. participatory decision making, trust); and (v) level (horizontal or vertical, i.e. within an actor group or among different actors). These characteristics describe the structure of the organization of a collective activity and the interrelationships between the actors and are an important determinant for the outcome of the activity for market participation and biodiversity. As already mentioned, it is especially the governance of the collective and the degree of participation of the members that is expected to be critical for its success. 
The performance of a market chain in the S-C-P approach can be measured in terms of the "three Es": Effectiveness, Efficiency and Equity. According to Holtzman (1986) 'effectiveness' is defined as "the matching of supply and demand at each level of the production/marketing system." Effectiveness can be measured by the stability of supply, the maintenance of product quality, the duration of the delivery process, and the product variety and assortment. The term 'efficiency' here refers to a situation wherein resources are used optimally, i.e. where they create the most benefit and prices are in line with costs. The term 'equity' concerns the power relations in the market chain (Keizer 2003). In an equitable market chain margins, bargaining power, and risk are distributed equally among the actors.

Although the establishment and strengthening of farmer groups has the potential to overcome many of the marketing problems smallholders face, it is not a panacea; problems exist such as free riding of some group members and a lower level of flexibility to respond to changes in the production or market prices and demand. Furthermore there is often a need for investments at two levels: i) at the individual farmer level to acquire and maintain membership or as initial starting capital, and ii) at the group level to build the capacity of smallholders to collaborate and build trust among them. Collective action may therefore not always be accessible for the most resource poor smallholders as they lack the investment capital, although it definitely has the potential to be more inclusive of the poor than contract farming. Even if there is a willingness and motivation to collaborate and investment capital is available collective action may still not be successful and sustainable or even desirable. Factors such as the composition of the group (e.g. gender, age, level of education, group size, assets of individual members, heterogeneity), previous experiences with collective action of the members, product characteristics and the type of market that is targeted to enter will greatly influence the outcomes of collective action (McCarthy 2004). 


\section{CASES}

The case studies analyzed in this paper have been developed in line with the revised strategy of the Bioversity International which focuses on improving people's lives through the deployment of useful agrobiodiversity. The five case studies, cowa in Thailand, kokum in India, laurel and caper in Syria and coconut fiber in Vietnam, have been carried out in the context of projects that aim at utilizing underutilized species, commodities and tropical fruits to enhance livelihoods of people. Data was collected between 2003 and 2006. The cases are diverse, owing to the differences in approaches employed and species studied, but are similar in their purpose to demonstrate the impact of markets for biodiversity products on livelihoods. The studies are all mostly descriptive and data was mainly collected through semi-structured or informal interviews. In some cases focus group discussions were carried out.

\section{Garcinia Species in Thailand and India}

In the South and Southeast Asian region tropical fruits play an important role in people's livelihoods and for their food security. This diversity is threatened by increased deforestation, indiscriminate harvesting practices and land use conversion, and monoculture (IPGRI 2003). Therefore, a project has been developed that deals with the sustainable management and utilization of tropical fruits in this region. The following two case studies were conducted in the context of this project and were specifically aimed at understanding the role of markets for tropical fruit tree diversity and livelihoods. The first case is a documentation of a good practice of marketing a biodiversity product in Thailand. The second case presents the results of a study conducted in India and presents the case of a cooperative retail outlet. Both cases deal with a species of the Garcinia genus.

\section{Cowa in Thailand}

Sthapit et al. (unpublished) have observed that the monitoring of sustainable use and management of diversity has been insufficient, especially among perennials and that it is therefore necessary to identify a set of good practices that support conservation and sustainable utilization of diverse tropical fruit species. It is important to understand the situation in which these practices are successful and to identify their role in responding to pressures urging farmers to switch to modern 
plant varieties. In order for a good practice to be sustainable it is also a prerequisite that it gives sustainable benefits to farmers (Sthapit et al. unpublished).

The case presented here deals with a women's group that is considered to be highly successful. The group is based in Chanthaburi province in Thailand and is processing several products derived from a range of tropical fruits, one of which is Garcinia cowa, commonly known as cowamangosteen or cowa. Informal interviews with women self-help groups were undertaken to understand the situation in which their processing activities have become successful.

The group, which was established in 1983, was the first cooperative group in their district. In recent years it has joined the 'One Tambon One Product' (OTOP) program, which is based on a similar Japanese program and was put in place by the Thai government in 2001 to improve the locally available resources and produce goods that are acceptable internationally in order to help encourage and promote tourism in Thailand down to the village (tambon) level and increase rural income from the sale of their products (OTOP website4).

The group was established after a major storm damaged the community's durian and mangosteen trees and caused the still immature fruits to drop. Quality of these fruits was considered to be too low to be marketed as fresh products and therefore some of the female members of the community decided to process the fruits in their homes. The district's agricultural extension office assisted them in the establishment of the cooperative and provided capacity building on processing. This encouraged the group to process more frequently from their homes and start including other species. After producing for thirteen years the group had managed to streamline the organization and had become an example for other groups, illustrated by the receipt of a provincial award for the governance and performance of their organization. At that time (1996) the cooperative was producing several products among which a local dish with cowa leaves (called Moochamung) and has until now continued doing so. Raw material for the cowa product is procured by the cooperative from its members, who harvest the fresh, young shoots from their homegardens and in some cases from the wild. When trees become too high to easily harvest the leaves, they are either cut halfway or new seedlings are planted, which illustrates their willingness to maintain cowa in their homegardens (Kruijssen and Somsri 2006).

4 OTOP website: http://www.thai-otop-city.com/background.asp. Accessed on 25-08-2006. 
Supported by the department of agricultural extension, processing equipment was purchased and in 2002 a small outlet and a processing facility were built. Presently the women's group consists of 40 members, who each can buy cooperative shares at 100 Thai bath (equivalent to US\$2.66) per piece as an investment in the cooperative. At the end of each year profits to their investments are paid out to the members. Members also receive wage payment for their labor and the group provides credit to its members. Hence, owing to their collective action women have substantially increased their income from tropical fruit tree products and have overcome the problems of oversupply of some fruits. Their group organization has given them access to the appropriate training needed to successfully apply for the food hygiene and safety certification and join the OTOP programs highest product quality level.

\section{Kokum in India}

Data for this case was collected through key informant interviews, questionnaires and an informal group discussion in Uttara Kannada district in Karnataka and Sindhudurg district in Maharashtra in India.

Kokum (Garcinia indica) is an underutilized fruit tree, native of the Western Ghats in India, mainly growing in the western parts of Maharashtra, Karnataka, Kerala and Goa. The fruit is used as a treatment for obesity; the rind as souring and food coloring agent, and fat of the seed is extracted for cosmetic and confectionery preparations.

In Uttara Kanada district, collectors of kokum are severely constrained in the marketing of their product because of legislation by the Forest Department. Collection from the wild is only allowed if a permit is obtained, which can only be done by entering into a tender system. Unorganized collectors are unable to obtain this license and owing to the unavailability of agricultural land and thus their high dependence on the forest resources for their livelihoods, they are forced to collect illegally and sell the products through middlemen that have been able to obtain the license. This clearly forms a severe limitation of their bargaining power. Prices they receive for the dried fruits are extremely low and have been decreasing in recent years, resulting in the abandonment of the collection of kokum. For these collectors, who are living below the poverty line and depend on forest products and occasional wage labor this has had a major impact on their livelihoods. A higher degree of collective action could enable them to obtain a license as a group; this would however require some public intervention and capacity building.

Small-scale farmers in Sindhudurg are able to market their produce through a horticultural cooperative which provides them with a relatively secure outlet for their dried kokum rind and the 
kokum seeds. A major difference between these farmers and the collectors in Uttara Kanada is that they are not facing the same licensing problem because they are growing kokum in their farmer fields and occasionally collecting from the wild. The horticulture society has approximately 9,000 members from all over the state, of which about 3,000 have some kokum trees, and 24 collection centers exist where members can sell their horticultural products to the society. The seed is separated from the pulp and the ripe and unripe rind is dried, resulting in 'sole', a product that is used in curries for souring as a replacement of tamarind. This product is packed by the society and sold in its bazaars. The seeds are sold separately to processing units in Kudal in the state of Maharashtra and to Vijayawada in the state of Andhra Pradesh. These processing units transform the seed into kokum oil or butter, which is considered to be a high value product and is used in cosmetic products and for cooking purposes. The cooperative provides the farmers a guaranteed outlet for part of their product, but demand for 'sole' is limited. The seed is much more important in terms of quantity and can be sold to distant processors owing to the intervention of the society that guarantees sufficient quantity for economies of scale (Kruijssen and Sudha, forthcoming). The organization of the society is highly hierarchical and there is a large group of administrative staff. This makes the society less flexible for changes in the market and gives the individual farmer limited influence on the society's activities.

\section{Capers and Laurel in Syria}

Pilot studies carried out on capers and laurel in Syria aim at showing how resource poor rural communities have developed markets for local biodiversity-derived products. The results show the potential of biodiversity, including underutilized species, to make a significant contribution to livelihood security in communities that inhabit difficult environments with unique resources. The study also highlights the importance of local cultural knowledge and institutions in sustainable development of markets of biodiversity products (Giuliani 2007).

\section{Capers}

Caper (Capparis spinosa L.) is a spiny perennial shrub, which can be found growing wild in Syria around dry and rocky areas. While caper is widely cultivated in other Mediterranean countries, in Syria caper is a wild species and is cultivated only on an experimental level in research nurseries. Unlike in other countries, in Syria caper is not used for food. Its medicinal use is also quite limited. The caper buds, collected before the flowers have formed, are therefore mostly used as export items in Syria. According to the pilot research study we carried out in Syria on the market chains of selected 
underutilized plant species, the collection of caper flower buds was started in Syria only recently by nomadic communities (Giuliani and Padulosi 2005).

The study involved a market chain analysis linked to the analysis of livelihood strategies of the caper market chain actors, including collectors, processors and traders, policy makers and cultivation specialists. Constraints and opportunities for improving the market chain organization were widely discussed stirred by a participatory multi-stakeholder workshop, where all actors involved in the chain met to discuss options for re-organizing the chain, in particular to benefit the most vulnerable actors, the collectors. This process was based on some elements of the Participatory Market Chain Approach (Bernet et al. 2006).

The pilot study and the following participatory market chain development process revealed some areas where collective action is already practiced and others where collective action bears an unexploited potential for improving the market benefit of small-scale producers. Collectors of capers are usually young children and women. The collectors jointly give a chief collector, normally a male who is a collector but also a trusted person in the community, the responsibility to gather the produce and liaise with a middleman. Despite the wide geographical spread of the collectors the chief collector is linking individuals to form a small informal group, so they can provide a larger quantity of caper buds to a trader. An example of this emerging collective action among the collectors was developed in the Rowheb village (North-East of Syria) by the village chief collector's initiative who saw potential for income generation for the collectors by linking them directly to an export trader. The major potential of this kind of action was shown in the multi-stakeholder workshop, during which the traders and exporters expressed great interest in cooperation with farmers groups (Giuliani and Buerli 2006). Aside from expecting reduced costs for transport as higher quantities can be bought from one place, traders would also be ready to pay a better price for good quality caper buds. The formation of collector groups would enable the traders to provide appropriate information or even training to collectors who are lacking the knowledge about which characteristics of the caper buds are most in demand. Collective action among collectors thus has two major benefits for these poor small-scale producers that are currently only partly realized: (1) it provides them with better access to information and (2) enhances their negotiation power due to higher quantities.

\section{Laurel}

Laurel (Laurus nobilis L.) is an evergreen forest tree of the Laureaceae family, which grows wild along the coastal area of Syria, an environment for which it is ideally suited. Its fruits are small and round (or oblong), with very dark berries that ripen between October and December. Oil extracted 
from the berries has been used for centuries in traditional Syrian products, such as laurel oil and laurel soap. Age-old methods transferred through generations are used to produce unique cosmetic products that are sold in local markets, in particular the ghar (laurel) soap, known for its unique perfume and its skin caring properties. Although the local and regional demand has remained stable for decades, export demand has grown recently, in particular for European, US and Japanese nature shops, creating new income-generating opportunities for Syrian producers.

A market chain analysis undertaken in this study involved interactions with collectors, oil and soap processors, traders, officers of the Forestry Department and cultivation specialists. It aimed to identify ways to generate market value to increase the income of the people involved in the marketing and production of laurel products.

In the mountain region in Syria, villagers collect berries from wild laurel trees on state land. A law setting specific rules and regulations concerning responsibilities for the protection, investment and commercial use of all forest species is limiting the collection of the laurel berries to household use, and forbids commercial use. Also, the growing of laurel trees on private lands is discouraged by the fact that the law forbids their harvesting. Nevertheless, the laurel berries are collected from the wild trees for commercial purposes and informal agreements among the households regulate to which laurel trees they have access. The selection criterion for the access to trees is based on the vicinity of the wild trees to their home gardens. These informal rights, agreed and recognized within the community, are transferred from generation to generation. The collection is done by each household separately. The oil is extracted manually by each household using traditional methods. This labor intensive process is primarily done by women and children in their gardens and there is no form of processing and product quality control. Each household sells its produce to the local soap makers and to traders. The local soap maker or the trader always buys the oil from the same households, and then re-sells the oil as final product at the city markets of Aleppo and Damascus. Lack of collective action between collectors or processors reduces their bargaining power in this process. There is a great level of mistrust between the collectors and the soap maker (or the oil trader working for him). The soap maker tries to pay the lowest possible price for the oil sold by the collectors. On the other hand, the collectors try to lower the quality of the oil. This attitude further reduces the trust between the two parties. A formation of a collector group that would allow a more stable supply and price is also discouraged by the law forbidding the collection of the berries and limiting the growing of the laurel trees. Hence, the supply of laurel oil remains scarce and scattered, of low quality and is thus insufficient for the soap makers, who import the oil mainly from Turkey. 
In the village of Kassab, on the North West of Syria, at the border with Turkey, there has been a first attempt at collective action, fostered by a local soap producer, bringing together a group of collectors that live in the forest area where laurel trees grow. The aim is the production of high value soap for the local market and a growing export and niche market, to create jobs for local people and improve the livelihoods of households involved in the production of laurel oil and soap in Syria. The soap producer tried to face the constraint of the existing forestry regulations and the missing clarity in its application by involving the collectors living in the community to lobby for their improvement towards sustainable collection from the wild and harvesting on private land. This would also allow for better conservation of this biodiversity resource. In addition, the factory needs a stable supply of the laurel oil and a higher quality of the laurel products, with higher quality standard of oil and soap, suitable packaging, information on the products, etc. to exploit the full market potential. These improvements are too expensive for individual households. For these reasons, collective action among households has been identified as a way to take advantage of this opportunity. Collector groups could have easier access to appropriate technology for oil extraction, training and quality control and getting a higher income.

\section{Coconut in Vietnam}

Coconut is generally grown on poor land by poor people. Around 96 percent of coconut farmers are smallholders tending less than four hectares (Batugal 2003). Lack of market information and access to markets is a major cause of poverty in many coconut growing communities. Because of limited market opportunities, rural coconut producing families often have little alternative than to sell the raw product, copra, which is a low-value commodity. Diversification of coconut products could reverse this situation coupled with addressing the marketing issues dominating the industry. Bioversity-COGENT designed and implemented the Poverty Reduction in Coconut Growing Communities project to enable farmers to produce high-value marketable products from coconuts and secure an additional source of income to support their families. This case focuses on the processing of coco fiber through the introduction of village level processing technologies by a local community in Vietnam.

Collective action at village level can make a major contribution to farmers' livelihoods. This is illustrated by the case of the Tam Quan Nam Community-Based Organization (CBO) in Binh Dinh province in Vietnam. Tam Quan Nam is a very poor coconut growing community, populated mostly by aging women and children below 16 years of age. Most of the men have gone to the city in search 
for work. With assistance of the project the CBO members identified an opportunity to increase the efficiency of coconut husk processing. The old practice of removing the husk and beating it into fiber by hand was hard work and very labor intensive, especially for the elderly women.

The project collaborated with a local government institute (the Oil Plant Institute of Vietnam) which initiated an integrated approach to bring processors and traders together. A collective loan in the form of a set of beating and decorticating machines to produce the fiber out of the coconut husks was provided for by the project. The project also lent 150 single and double-rope twining machines to individual CBO members. The beating and decorticating machines are operated by the CBO's management. The individual CBO members queue up early in the morning to get their supply of fiber from the $\mathrm{CBO}$ which they process into rope using their twining machines. The $\mathrm{CBO}$ then buys back the rope (after deduction of the cost of the fiber) which in turn is processed into various products, such as doormats and geotextiles. The manufacturing of the various end-products in the community itself increases employment opportunities for a large number of non-member workers. The CBO members volunteer to sell their raw product, the coconut husks, to the CBO management at a slightly lower price than they would be able to obtain in other markets. In return they benefit from a stable and higher income through the making of ropes and doormats, which are collectively processed and marketed by the $\mathrm{CBO}$. Through an increased volume and wider range of products the $\mathrm{CBO}$ has a stronger negotiation position than the individual members would have on their own. The joint venture also increases mutual trust and friendship amongst the members, who would otherwise be competitors.

Owing to the rope-making machines and the collective marketing, the women can now produce much more rope than when they were making twines manually. The investment for the machinery (US\$ 30-35) is repaid through deduction from the members' sale of ropes to the CBO. In the past, when the women were making ropes manually and were working individually rather than as a collective, each used to earn VND 4500 (US\$ 0.30) per day. Now members are making VND 18000 to VND 20000 (US\$ 1.20 to US\$1.33) each day. Facilitated and encouraged by their success the $\mathrm{CBO}$ has tripled the capacity through investing in additional beating and decorticating machines. Owing to the increase in income from coco-based processed products, farmers value their coconut plantations more and are conserving their existing coconut palms, contributing to maintaining genetic coconut diversity in the area (Keizer 2005). 


\section{COMPARATIVE ANALYSIS}

Previously we have explained the importance of understanding the process of collective action, the governance structure of a collective and the outcomes for market participation and described some of the important concepts. In this section we analyze our cases according to this process and the outcomes for market access. The information presented in Table 1 provides an overview of the cases described in this paper categorizing them according to the elements of the conceptual framework. This gives us insight into the range of options and situations in which collective action can encourage market development and consequently support livelihoods and stimulate the management of agrobiodiversity on-farm.

The cases presented in this paper show that collective action is a social process that can be triggered by a range of factors. The cowa case from Thailand shows how a group of befriended women initiated the idea of processing fruits in order to utilize their resources. The initial success and the strong presence of shared values, agreements and trust among the women provided the engine for further social learning, 'collective cognition' and capacity building. The case illustrates that this process can be a catalyst for institutionalizing collective action, as government agencies and NGOs stepped in (upon request by the women's group) to provide capacity building and technical equipment, thus accelerating social learning and facilitating the formation of social capital. These collective activities can be considered highly successful in terms of market performance and biodiversity maintenance. However this case also indicates the continuous investments that are required from the members, for which returns are paid annually. Benefits are higher for those who have access to a higher level of investment capital. Although the COGENT coconut project in Vietnam seems to have substantially increased income, it also required a very high level of external investment, both in terms of capacity building and capital for machinery. The same is true for the cowa case where governmental and non-governmental organizations stepped in and contributed to the formation and operation of the collective.

Some of the communities in the case studies still lack a catalyst that can help to trigger the process of collective action. For example in the first district in the kokum case in India, where legislation hampers individual collection of kokum fruit from the wild forest lands, the formation of collector groups might provide a solution to empower them. However they presently lack the resources and the capacity to start the process of collective action themselves. These collectors and those in the communities in the Syrian cases on laurel and caper are still at the beginning of the social learning process. Despite the emergence of agents that organize the women caper collectors, there is 
still a high level of distrust among the market chain actors and lack of equity towards the most vulnerable actors in the chain - the collectors. The laurel case shows that on the one hand collective action is hampered by legislation (it is forbidden to commercially harvest and market laurel), while on the other hand there is a need for a joint platform for negotiation (e.g. through dialogue and collective action) to solve conflict between lawmakers and communities.

When public institutions attempt to trigger collective action and operate as a driver of the process there is a need to ensure that the prerequisites are in place. Through the use of participatory approaches involving the communities that are targeted it should first of all be established whether there are no alternative solutions to collective action, which may come with high initial investments. Secondly it needs to be assessed whether there is a willingness and sufficient interconnectedness to enable collaboration. Although ownership of the process and trust between the participants may be created and built upon during the social learning process, some level needs to be already present in order for the collective to be successful. The case of laurel is an example of a situation in which trust was a major constraint among the actors at different levels in the market chain. The initiative of the soap processor to engage with the farmers could be a means to overcome this, but distrust could also be a major impediment for further development of the collective process.

If communities are not triggered from within by a private initiative or external community support projects such as the COGENT coconut project in Vietnam, catalysts may emerge "further down" in the market chain. This was shown by the initiative of the soap processor in the laurel case. Such individuals are often commercially motivated and business minded which makes it more difficult to ensure the benefit of the community. This however, does not necessarily mean that the community should be worse off; their link with a reliable market actor has the potential to secure the outlet for their produce. In this case the entrepreneur that triggered the process, acknowledged the mutual interdependence among the actors (through discussions in multi-stakeholder workshops) and the need for the active involvement of producers or collectors for quality advancement and stability of supply and the improvement of regulations, and therefore stimulated the formation of producer groups.

In both cases in Syria, the process of the emergence of collective action, which is still at an early stage, has been initiated by a key person with initiative and motivation, a "chain champion," which had an impact on the group formation and functioning. In the case of caper, this key person, who is one of the collectors, understood the potential for income generation of the collectors through the direct link with an export trader. In the laurel study, the key person is found "further down" in the market chain, in the form of the soap processor. 
Collective action can thus provide a strong basis for creating greater market effectiveness as well as improve its efficiency by a more stable and higher quality supply of raw material by the group. In all cases improved trust and connectedness among the various actors is already present or expected, within and across the groups. The higher bargaining power and improved access to markets for group members, are made possible by creating a link with other actors along the chain (bazaars, traders and processors for kokum, the export trader for capers, and the soap maker for laurel, end users of coconut fiber products) and as a consequence contribute to more equitable rent distribution along the market chain.

The internal governance structure of the cases presented, range from very hierarchical in the case of the horticultural society marketing kokum in Sindhudurg, to democratic in the cowa and coconut cases, to very informal in the capers and laurel cases. The case studies did not accurately measure the equitability within the groups, although some indication about the level of equity can be given. In the case of cowa it becomes clear that returns are distributed according to investments. Individual annual income from participation in the group will depend on the availability of working capital of a particular household at the start of the year. All members have an equal opportunity to contribute labor for the processing of the products and thus earn additional income from wages, although this will also depend on their other activities in the household, on-farm or off-farm. The democratic structure of this women's group and the relative small size ensure that the power balance within the group is fairly even. In the case of coconut where the costs of raw material (coconut fiber) are deducted only after the rope is returned to the cooperative, a lack of investment capital may not hinder the community members from earning a higher income. Both men and women are able to utilize the rope-making machines and in this way they are both able to provide income to the household. Therefore it rather is the availability of labor within the household that is the limiting factor for a further increase in household income in this case. The kokum case illustrates that farmers are willing to accept a lower price for their kokum from the society compared to marketing it individually in the local market, because it allows them to use this time for other activities. The society fulfils an important role and therefore absorbs part of the margins in the chain. In the case of laurel, an income increase coming from the market of the final product is fairly evenly distributed among the group members. Because the market of capers is much less organized and transparent and the emerging collective action only regards the collectors and the chief collector among the market chain actors, an increase in the income of the caper traders is not equally reflected in the income of caper collectors. 
The case studies also indicate the importance of collective action for the maintenance of biodiversity on-farm. In the laurel and caper cases, where species are collected from the wild, collective action brought awareness of the need for sustainable collection methods and cultivation of commercial species. This could have a positive impact on the conservation of biodiversity related to these local wild species and varieties. The social learning process also raised awareness of the need to link regulations on biodiversity conservation and economic exploitation. A higher perceived value for coconut trees created by the high value products of coconut fiber, offers an incentive for increasing the maintenance of the local coconut varieties. The same is also happening in the case of cowa where the production of local products provides an incentive for the planting of new seedlings. The case of the two districts growing kokum demonstrates that a reduction of the utility of a certain species for a farmer due to obstacles in the market chain also reduces the incentive to conserve this species. Conversely, when the market chain is more secure for example by means of collective action, smallholders preserve an incentive for biodiversity maintenance on farm. The improved market outlet for the products derived from biodiversity may also have an accelerating effect on investments in the market chain. And whereas the promotion of individual smallholders will only benefit a few, spending on collective action will have the potential to benefit more (and poorer) growers and collectors.

The investments that were made into the cases originate both from the public and the private sector. High public sector investments were used in the cowa (government program) and coconut (research institute project) cases. The horticultural society in the kokum case is a private initiative and investment capital comes from the members themselves. In the case of Vietnam the local government supported the project with rope making machines after they observed the initial success of the project and the support of the local government was vital for the sustainability of the project as it created the appropriate and conducive environment.

Although some of the cases indicate that collective action can be a useful tool to link smallholders to markets and increase their income and at the same time ensure the maintenance of biodiversity, it is not the only method to reach these goals. As was explained in section 2 there are many pre-conditions that have to be fulfilled before there is a chance of successful and sustainable collective action. Furthermore it can be very costly to initiate such collaboration. For the cases of the unorganized kokum collectors in Uttara Kanda, and the cases of capers and laurel in Syria, where a collective action is presently nonexistent or very limited, alternative interventions may be less capital intensive and possibly more effective. Policy interventions for the kokum case could for example include the amendment of the present legislation coupled with some capacity building of the farmers to improve their marketing skills. This will however not resolve their high transaction costs that are 
inherent to their limited scale. This is similar in the Syrian laurel case where a revision of legislation could also provide increased opportunities for the collectors. In the case of capers in Syria, national level research on traits, uses and adaptation is required to assure a reliable supply of the product. The improvement of the linkage of smallholders to the markets could also be reached by stronger vertical integration of the market chain. This may however also require substantial investments at individual farmer level in order for smallholders to reach the level of quality standards, more efficient processing methods and improved marketing of the final product as well as the stability of supply that is required. 
Table 1. Comparative analysis

\begin{tabular}{|c|c|c|c|c|c|}
\hline Case & Cowa Thailand & Kokum India & Caper Syria & Laurel Syria & Coconut fiber Vietnam \\
\hline Form of CA & Women self help group & Horticultural society & $\begin{array}{l}\text { Informal start of a vertical } \\
\text { integration: collectors' } \\
\text { group-soap factory }\end{array}$ & Informal collectors' group & $\begin{array}{l}\text { Community based } \\
\text { organization }\end{array}$ \\
\hline Trigger & $\begin{array}{l}\text { Community requested } \\
\text { assistance from } \\
\text { governmental institution } \\
\text { because of need for } \\
\text { processing }\end{array}$ & Private initiative & $\begin{array}{l}\text { Private initiative (by chief } \\
\text { collectors, trusted by the } \\
\text { collectors) }\end{array}$ & $\begin{array}{l}\text { Private initiative (by soap } \\
\text { producer involving laurel } \\
\text { berry collectors) }\end{array}$ & $\begin{array}{l}\text { Bioversity International } \\
\text { project intervention }\end{array}$ \\
\hline Status & $\begin{array}{l}\text { Established in } 1983 \text {. Recent } \\
\text { OTOP member }\end{array}$ & Old cooperative & $\begin{array}{l}\text { New informal collectors' } \\
\text { group }\end{array}$ & $\begin{array}{l}\text { New informal collectors' and } \\
\text { processors' group }\end{array}$ & CBO established in 2002 \\
\hline Size & $\begin{array}{l}40 \text { community women, } \\
\text { producers }\end{array}$ & $\begin{array}{l}9000 \text {, of which } \\
\text { approximately } 3000 \text { with } \\
\text { kokum producers }\end{array}$ & $\begin{array}{l}\text { About } 30 \text { collectors and a } \\
\text { chief collector }\end{array}$ & $\begin{array}{l}1 \text { small-scale business, about } \\
10 \text { collector households }\end{array}$ & $\begin{array}{l}160 \text { community members, } \\
\text { producers }\end{array}$ \\
\hline Activities & $\begin{array}{l}\text { Processing, marketing of } \\
\text { selected tropical fruits }\end{array}$ & Horticultural trade & $\begin{array}{l}\text { Gather the collection from } \\
\text { the wild and selling directly } \\
\text { to a trader (for export } \\
\text { market) }\end{array}$ & $\begin{array}{l}\text { Gather the collection of } \\
\text { berries from the wild and } \\
\text { trading laurel oil. Advocacy } \\
\text { for a better regulation }\end{array}$ & $\begin{array}{l}\text { Processing and marketing of } \\
\text { fiber based products }\end{array}$ \\
\hline Functions & Economic, social & Economic & $\begin{array}{l}\text { Marginal income generation } \\
\text { (economic) }\end{array}$ & Economic, social & Mainly economic \\
\hline Governance & $\begin{array}{l}\text { Democratic, members buy } \\
\text { shares }\end{array}$ & Very hierarchical & Informal & Informal & $\begin{array}{l}\text { Democratic, members have } \\
\text { the right to vote }\end{array}$ \\
\hline Level & $\begin{array}{l}\text { Producer / processor (within } \\
\text { actor group, but vertical } \\
\text { integration) }\end{array}$ & $\begin{array}{l}\text { Producer (within actor } \\
\text { group) }\end{array}$ & $\begin{array}{l}\text { Collectors (within actor } \\
\text { group, horizontal } \\
\text { integration) }\end{array}$ & $\begin{array}{l}\text { Collectors (producers) / } \\
\text { processors (an attempt of } \\
\text { vertical integration) }\end{array}$ & Producers and processors \\
\hline Outlet & $\begin{array}{l}\text { Tourist shops, OTOP fairs, } \\
\text { local market }\end{array}$ & $\begin{array}{l}\text { Cooperative bazaars, other } \\
\text { retailers, processors }\end{array}$ & $\begin{array}{l}\text { Link to export market } \\
\text { through local trader }\end{array}$ & $\begin{array}{l}\text { Local market, access to } \\
\text { export market through the } \\
\text { soap maker }\end{array}$ & $\begin{array}{l}\text { Domestic market through } \\
\text { local traders }\end{array}$ \\
\hline
\end{tabular}




\begin{tabular}{|c|c|c|c|c|c|}
\hline Case & Cowa Thailand & Kokum India & Caper Syria & Laurel Syria & Coconut fiber Vietnam \\
\hline $\begin{array}{l}\text { OUTCOME } \\
\text { marketing \& } \\
\text { social }\end{array}$ & $\begin{array}{l}\text { Members have guaranteed } \\
\text { outlet for own raw material } \\
\text { and are able to market the } \\
\text { products under a label thus } \\
\text { increasing the effectiveness. } \\
\text { They benefit from additional } \\
\text { income from value addition } \\
\text { and risk is equally } \\
\text { distributed among the } \\
\text { members. Their status as an } \\
\text { OTOP group also enhances } \\
\text { their bargaining power, } \\
\text { positively affecting the } \\
\text { equity in this chain. }\end{array}$ & $\begin{array}{l}\text { The members have a more } \\
\text { secure outlet for their semi- } \\
\text { processed product, however } \\
\text { only up to a certain level; } \\
\text { therefore effectiveness is } \\
\text { only partially increased. The } \\
\text { society is very hierarchical } \\
\text { and due to the limitations in } \\
\text { the quantity accepted } \\
\text { bargaining power for } \\
\text { members is reduced; hence } \\
\text { also equity in the chain is not } \\
\text { much enhanced. Due to its } \\
\text { size the cooperative is } \\
\text { definitely able to capture the } \\
\text { benefits of economies of } \\
\text { scale and therefore } \\
\text { efficiency is greatly } \\
\text { enhanced. }\end{array}$ & $\begin{array}{l}\text { Increased market access and } \\
\text { higher price for collectors } \\
\text { due to increased supply } \\
\text { reliability for the trader. } \\
\text { Effectiveness of the supply } \\
\text { chain is enhanced by better } \\
\text { linkage to exporters, as is } \\
\text { efficiency through } \\
\text { transaction cost reduction. } \\
\text { As traders are willing to pay } \\
\text { higher price for quality } \\
\text { capers equity is improved as } \\
\text { well. }\end{array}$ & $\begin{array}{l}\text { Increased income for the } \\
\text { laurel berry collectors and } \\
\text { soap producer. Call for } \\
\text { improved management of } \\
\text { forest resources to secure oil } \\
\text { supply. Job creation within } \\
\text { the community due to the } \\
\text { enlargement and } \\
\text { improvement of activities } \\
\text { related to laurel oil and soap } \\
\text { production (in particular, for } \\
\text { women). Collective action } \\
\text { therefore has the potential to } \\
\text { greatly improve the } \\
\text { performance of the market } \\
\text { chain. }\end{array}$ & $\begin{array}{l}\text { The equity of the chain is } \\
\text { improved as bargaining } \\
\text { power is enhanced by } \\
\text { trading larger quantities, } \\
\text { which also improves } \\
\text { efficiency. This leads to } \\
\text { increased incomes. Spillover } \\
\text { effects lead to job creation } \\
\text { within the community. }\end{array}$ \\
\hline $\begin{array}{l}\text { OUTCOME } \\
\text { Biodiversity }\end{array}$ & $\begin{array}{l}\text { Fruit species preserved in } \\
\text { homegardens because of new } \\
\text { outlet }\end{array}$ & $\begin{array}{l}\text { Guaranteed outlet, but small } \\
\text { quantities, still incentive to } \\
\text { preserve trees }\end{array}$ & $\begin{array}{l}\text { More sustainability in } \\
\text { collection (cultivation and } \\
\text { conservation of wild } \\
\text { varieties) }\end{array}$ & $\begin{array}{l}\text { More sustainability in } \\
\text { collection (cultivation and } \\
\text { conservation of wild } \\
\text { varieties). Awareness of the } \\
\text { need of linking and } \\
\text { combining regulations on } \\
\text { biodiversity conservation } \\
\text { and economic exploitation }\end{array}$ & $\begin{array}{l}\text { Higher perceived value for } \\
\text { coconut trees gives incentive } \\
\text { for increased maintenance, } \\
\text { however low level of } \\
\text { biodiversity present and } \\
\text { therefore weak link with } \\
\text { biodiversity }\end{array}$ \\
\hline
\end{tabular}




\section{DISCUSSION AND CONCLUSIONS}

The cases presented have illustrated that improved market participation has the potential to increase farmer utility for agrobiodiversity and therefore stimulate on-farm biodiversity maintenance, although this relationship is not always equally strong or straight forward. Although this paper has not uncovered the underlying reasons for that, it nevertheless has become clear from some of the cases that the involvement of producers and collectors in the social learning process is important for more environmental sustainability. If the involvement of other market chain actors is ensured as well, this process can form the basis for the trust and connectedness that is needed for long-term planning. Social capital can lead to the reduction of individual risks essential for the facilitation of long-term investment thus enabling sustainable harvesting and investments in processing technology and planting material. The specific characteristics of many agricultural products such as high perishability, seasonality and price volatility also call for specific knowledge, for example on hygiene, standards and labeling, access to which can be facilitated by the formation of a collective.

Although the potential of collective action for smallholder linkage is undoubtedly present it does not offer a solution in all situations, nor is it without costs. A high level of efforts and investments is required to achieve successful and sustainable collaboration between individual smallholders. Based on the cases presented in this paper we are unable to conclude whether public or private investments are more suitable for this type of interventions. It seems that at times public spending is necessary to create the requirements for private investments. Private investors are increasingly becoming aware of the potential of improving smallholder market chains and public funds should therefore be utilized for the most marginalized farmers that do not have access to private investments. Furthermore it was established that a certain level of trust and interconnectedness is required, along with pre-conditions in terms of group composition and market and product characteristics. The enabling environment, including the policy framework also needs to be conducive.

For the design of effective policies for biodiversity conservation and livelihood improvement trade-offs between income generation, livelihood security, and biodiversity conservation need to be taken into account. On one hand biodiversity affects poverty through providing livelihoods, affecting the health of the poor, and influencing their vulnerability. On the other hand poverty forces the poor to degrade natural resources (Jehan and Umana 2003). Many conservationists do not encourage diversity conservation through extractive use, since there are so many examples where this has lead to overexploitation. However, the use of living resources is also recognized to be an essential livelihood 
strategy for many of the poor, especially those in rural areas. Markets, although having the potential to raise demand for diverse products from different varieties, can also result in homogenizations and specialization. It is therefore of critical importance to identify whether a market-based strategy aiming at both income generation and agrobiodiversity conservation could be successful and sustainable (Rietbergen et al 2002).

In literature collective action for on-farm biodiversity conservation and more specifically the conservation of plant genetic resources has mostly been focused on the area of seed-supply systems and property rights (such as Badstue et al. 2006 and Eyzaguirre et al. 2004). This is based on the premise that collective action can improve the access to diversity and provide a means to conserve local knowledge and can increase the availability and exchange of information among farmers and aid the improvement of local varieties. As a group, farmers can also maintain more diversity than individually (Eyzaguirre et al. 2004). Whereas this approach is focused on the supply of diversity, in this paper we have examined the role of collective action for the demand for diversity and more specifically market-based methods to enhance the demand for diversity through increasing its value. The link between collective action and on-farm biodiversity management may therefore be indirect however, similar to the described approach of collective action for seed-systems, the networks established through a collective action will greatly enhance the information exchange and awareness about the biodiversity present on-farm.

Collective action clearly can play a major role in facilitating community based efforts for marketing activities and organizations such as Bioversity International can play an important role as the catalysts that trigger the start of the social learning process and the formation of social capital that needs to be at the basis of any intervention aiming for sustainable market development for agrobiodiversity products. A further understanding of the underlying mechanisms is necessary in order to find solutions that support sustainable development of poor communities that manage agricultural biodiversity. The example of the COGENT poverty reduction project that was presented in the coconut case indicates how Bioversity has implemented a project that has achieved significant poverty reduction and project beneficiaries were able to increase their incomes from fiber production by 300-400 percent through this collective approach (Van Long and Thi Le Thuy 2005). Although many factors that influence the success of these interventions are context specific, the same model was applied in several other countries within the same project. Presently this project also serves as a model for other planned interventions and proposed up-scaling and lessons learned from this project are transferred to governments and NGOs working on these issues. The implementation of these types of interventions will also require the development of specific capacity and analytical skills on both marketing and biodiversity. 


\section{REFERENCES}

Batugal, P. 2003. Poverty reduction in coconut growing communities: The framework and project workplan. In Poverty reduction in coconut growing communities Volume I: The framework and project plan, ed. P. Batugal and J.T. Oliver. Serdang, Selangor, Malaysia: IPGRI-APO.

Badstue, L.B., M.R. Bellon, J. Berthaud, X. Juárez, I.M. Rosas, A.M. Solano and A. Ramírez, 2006. Examining the role of collective action in an informal seed system: a case study from the Central Valleys of Oaxaca, Mexico. Human Ecology 34 (2): 249-273.

Bernet T., G, Thiele G., and T. Zschocke. 2006. Participatory market chain approach (PMCA) - User Guide. Lima, Peru: CIP,

Bosc, P. M., Eychenne., K. Hussen, B. Losch, M.R. Mercoiret, P. Rondot, and S.M. Walker. 2002. The role of rural producer organizations in the World Bank rural development strategy. The World Bank rural development family: Rural development strategy Background Paper. Washington, World Bank.

Campilan, D. 2002. Linking social and technical components of innovation through social learning. In Wheelbarrows full of frogs: Social learning in rural resource management, ed. Leeuwis, C. and R. Pyburn. Assen, The Netherlands.

Coleman, J. 1988. Social capital and the creation of human capital. American Journal of Sociology. 94: supplement S95-S120.

Coleman, J. 1990. Foundations of social theory. Cambridge, MA, Harvard University Press.

De Janvry, A. and E. Sadoulet. Making investment in the rural poor into good business: New perspectives for rural development in Latin America. Working paper prepared by the Conference on Developing the Rural Economy and Reducing Poverty in Latin America and the Caribbean, New Orleans, U.S.A. March 24, 2000.

Di Gregorio, M., K. Hagedorn, M. Kirk, B. Korf, N. McCarthy, R. Meinzen-Dick and B. Swallow. 2004. Property rights, collective action and poverty: The role of institutions for poverty reduction. Paper prepared for the Tenth Biennial Conference of the International Association for the Study of Common Property (IASCP), August 9-13, 2004, Oaxaca Mexico.

Eyzaguirre, P., N. McCarthy, M. Di Gregorio, and D. Evan, 2004. Property rights, collective action, and plant genetic resources. 2020 Vision Briefs 11 (10). Washington, D.C.: International Food Policy Research Institute (IFPRI).

Fliert, E. van der, R. Dilts and J. Pontius. 2002. Farmer researcher teams, farmer field schools and community IPM. In Wheelbarrows full of frogs: Social learning in rural resource management, ed. Leeuwis, C. and R. Pyburn. Assen, The Netherlands.

Giere, R. N. 2002. Discussion note: Distributed cognition in epistemic cultures. Philosophy of Science 69 (4): 637-644. 
Giuliani A., 2007. Developing markets for agrobiodiversity: Securing livelihoods in dryland areas. Earthscan Publications, London, UK and Bioversity International, Rome, Italy

Giuliani A. and M. Buerli. 2006. Reorganizing the market chain of capers in Syria: a multistakeholder process. Rural Development News 1/2006, LBL, Eschikon 28, 8315 Lindau, Switzerland. http://www.lbl.ch/internat/services/publ/bn/2006/01/reorganizing_the_market.pdf

Giuliani A. and S. Padulosi. 2005. Enhancing the value chain for markets for traditional producers of aromatic, vegetable and fruit species in the Near East: A pilot study in Syria. In Proceedings of the ICARDA International Conference on Promoting Community-driven Conservation and Sustainable Use of Dryland Agrobiodiversity, April 18-21, 2005, Aleppo, Syria.

Gruère G., M. Smale and A. Giuliani. 2006. Marketing underutilized species for the benefit of the poor: a conceptual framework. EPT Discussion Paper 154. Washington, D.C.: International Food Policy Research Institute.

Hotzman, J.S. 1986. Rapid reconnaissance guidelines for agricultural marketing and food system research in developing countries. Working paper No. 30, Michigan State University, Lansing, Michigan.

Jabbar, M.A., E. Tambi, and G. Mullins. 1997. A methodology for characterizing dairy marketing systems. Market-oriented smallholder dairying research. Working Document 3. Nairobi, Kenya: International Livestock Research Institute.

Jehan, S. and A. Umana. 2003. The Environment-poverty nexus. Development Policy Journal 3: 5370 .

Johnson N., R. Suarez, and M. Lund. 2002. The importance of social capital in Colombian rural agro-enterprises. CAPRi Working Paper No. 2. Washington, D.C.: International Food Policy Research Institute.

Jordan N., R. Becker, J. Gunsolus, S. White, S. Damme. 2003. Knowledge networks: an avenue to ecological management of invasive weeds. Weed Science 51 (2): 271-277

Keizer, M. 2003. The interface between producer and trader: Research into the sweet potato market in Bataan, Central Luzon, The Philippines. MSc thesis Unpublished. Wageningen University, the Netherlands.

Keizer, M. 2005. Increasing livelihood opportunities through market research and strengthening of market channels: Conduct of market surveys and development of market channels. In Poverty reduction in coconut growing communities Volume III: Project achievements and impact, ed. Batugal, P. and J.T. Oliver. Serdang, Selangor, Malaysia: IPGRI-APO.

Koelen, M. and E. Das. 2002. Social learning: A construction of reality. In Wheelbarrows full of frogs: Social learning in rural resource management, ed. Leeuwis, C. and R. Pyburn. Assen, The Netherlands. 
Kruijssen, F. and S. Somsri. 2006. Marketing local biodiversity in Thailand: Identification of a possible good practice for on-farm biodiversity management of tropical fruit trees. Contributed paper for the Deutscher Tropentag, "Prosperity and Poverty in a Globalised World - Challenges for Agricultural Research,” October 11-12, 2006, Bonn, Germany.

Kruijssen, F. and M. Sudha. Forthcoming. Enhancing biodiversity conservation and utilization for improved livelihoods - a case study of kokum in India. International workshop on tropical and sub-tropical fruits. November 27-30, 2006, Chiang Mai, Thailand. Forthcoming in Acta Horticulturae.

Marshall, G., I. Patrick, A. Muktasam and I. Ambarawati. 2006. Alleviating poverty by linking smallholders with agribusiness: roles of social capital and common property. Paper presented at the $11^{\text {th }}$ biennial conference of the International Association for the Study of Common Property, June 19-23, 2006. Ubud, Bali, Indonesia.

McCarthy, N. 2004. Collective action and property rights for sustainable development. Local-level public goods and collective action. In Collective action and property rights for sustainable development, ed. Meinzen-Dick, R. and M. di Gregorio. Focus brief. Washington, D.C.: International Food Policy Research Institute.

Pretty, J. and H. Ward. 2001. Social capital and the environment. World Development 29 (2): 209-227.

Rietbergen, S., J. Bishop and S. Mainka. 2002. Ecosystem conservation - A neglected tool for poverty reduction. WSSD Opinion Paper. London: International Institute for Environment and Development.

Schmalensee, R. 1989. Inter-Industry studies of Structure and Performance. In Handbook of industrial organization, ed. Schmalensee, R. and R. Willing. North Holland, the Netherlands: Elsevier.

Sexton, R. 2000. Industrialization and consolidation in the US food sector: Implications for competition and welfare. American Journal of Agricultural Economics 82 (5): 1087-1104.

Smale, M. 2004. The conceptual framework for economics research in IPGRI's global in situ conservation project. In The economics of conserving agricultural biodiversity on-farm, ed. Smale, M., I. Mar, D. Jarvis. Research methods developed from IPGRI's Global Project 'Strengthening the Scientific Basis of In Situ Conservation of Agricultural Biodiversity. Rome, Italy: International Plant Genetic Resources Institute.

Sthapit, B., P. Sajise, R. Rao, P. Quek, F. de la Cruz, and M. Bellon. Unpublished. Selection of Good Practices of in situ conservation of tropical fruit tree species diversity: methodology and key practices. Rome, Italy: International Plant Genetic Resources Institute.

The Tuan D., P. Moustier D. The Anh. 2006. Strengths and weaknesses of farmers' collective action: Some conceptual backgrounds. Presentation for the national workshop "Collective action and the participation of small farming households in the market - An opportunity to escape poverty for small farming household" May 11, 2006.

Uphoff, N.T. 1995. Grassroots organizations and NGOs in rural development: opportunities with diminishing states and expanding markets. World Development 21 (4): 607-622. 
Van Long, V. and N. Thi Le Thuy. 2005. Vietnam success stories. In Poverty reduction in coconut growing communities Volume III: Project achievements and impact, ed. Batugal, P. and J.T. Oliver. Serdang, Selangor, Malaysia: IPGRI-APO.

Vermillion, D. 2001. Property rights and collective action in the devolution of irrigation system management. In Collective action, property rights and devolution of natural resource management: Exchange of knowledge and implications for policy, ed. Meinzen-Dick, R., A. Knox, M. Di Gregorio. Feldafing, Germany: Zentralstelle fur Ernaehrung und Landwirtschaft (ZEL), Food and Agriculture Development Centre. 


\section{List of CAPRi Working Papers}

01 Property Rights, Collective Action and Technologies for Natural Resource Management: A Conceptual Framework, by Anna Knox, Ruth Meinzen-Dick, and Peter Hazell, October 1998.

02 Assessing the Relationships between Property Rights and Technology Adoption in Smallholder Agriculture: A Review of Issues and Empirical Methods, by Frank Place and Brent Swallow, April 2000.

03 Impact of Land Tenure and Socioeconomic Factors on Mountain Terrace Maintenance in Yemen, by A. Aw-Hassan, M. Alsanabani and A. Bamatraf, July 2000.

04 Land Tenurial Systems and the Adoption of a Mucuna Planted Fallow in the Derived Savannas of West Africa, by Victor M. Manyong and Victorin A. Houndékon, July 2000.

05 Collective Action in Space: Assessing How Collective Action Varies Across an African Landscape, by Brent M. Swallow, Justine Wangila, Woudyalew Mulatu, Onyango Okello, and Nancy McCarthy, July 2000.

06 Land Tenure and the Adoption of Agricultural Technology in Haiti, by Glenn R. Smucker, T. Anderson White, and Michael Bannister, October 2000.

07 Collective Action in Ant Control, by Helle Munk Ravnborg, Ana Milena de la Cruz, María Del Pilar Guerrero, and Olaf Westermann, October 2000.

08 CAPRi Technical Workshop on Watershed Management Institutions: A Summary Paper, by Anna Knox and Subodh Gupta, October 2000.

09 The Role of Tenure in the Management of Trees at the Community Level: Theoretical and Empirical Analyses from Uganda and Malawi, by Frank Place and Keijiro Otsuka November 2000.

10 Collective Action and the Intensification of Cattle-Feeding Techniques a Village Case Study in Kenya's Coast Province, by Kimberly Swallow, November 2000.

11 Collective Action, Property Rights, and Devolution of Natural Resource Management: Exchange of Knowledge and Implications for Policy, by Anna Knox and Ruth MeinzenDick, January 2001.

12 Land Dispute Resolution in Mozambique: Evidence and Institutions of Agroforestry Technology Adoption, by John Unruh, January 2001. 
13 Between Market Failure, Policy Failure, and "Community Failure": Property Rights, CropLivestock Conflicts and the Adoption of Sustainable Land Use Practices in the Dry Area of Sri Lanka, by Regina Birner and Hasantha Gunaweera, March 2001.

14 Land Inheritance and Schooling in Matrilineal Societies: Evidence from Sumatra, by Agnes Quisumbing and Keijuro Otsuka, May 2001.

15 Tribes, State, and Technology Adoption in Arid Land Management, Syria, by Rae, J, Arab, G., Nordblom, T., Jani, K., and Gintzburger, G., June 2001.

16 The Effects of Scales, Flows, and Filters on Property Rights and Collective Action in Watershed Management, by Brent M. Swallow, Dennis P. Garrity, and Meine van Noordwijk, July 2001.

17 Evaluating Watershed Management Projects, by John Kerr and Kimberly Chung, August 2001.

18 Rethinking Rehabilitation: Socio-Ecology of Tanks and Water Harvesting in Rajasthan, North-West India, by Tushaar Shah and K.V.Raju, September 2001.

19 User Participation in Watershed Management and Research, by Nancy Johnson, Helle Munk Ravnborg, Olaf Westermann, and Kirsten Probst, September 2001.

20 Collective Action for Water Harvesting Irrigation in the Lerman-Chapala Basin, Mexico, by Christopher A. Scott and Paul Silva-Ochoa, October 2001.

21 Land Redistribution, Tenure Insecurity, and Intensity of Production: A Study of Farm Households in Southern Ethiopia, by Stein Holden and Hailu Yohannes, October 2001.

22 Legal Pluralism and Dynamic Property Rights, by Ruth Meinzen-Dick and Rajendra Pradhan, January 2002.

23 International Conference on Policy and Institutional Options for the Management of Rangelands in Dry Areas, by Tidiane Ngaido, Nancy McCarthy, and Monica Di Gregorio, January 2002.

24 Climatic Variablity and Cooperation in Rangeland Management: A Case Study From Niger, by Nancy McCarthy and Jean-Paul Vanderlinden, September 2002.

25 Assessing the Factors Underlying the Differences in Group Performance: Methodological Issues and Empirical Findings from the Highlands of Central Kenya, by Frank Place, Gatarwa Kariuki, Justine Wangila, Patti Kristjanson, Adolf Makauki, and Jessica Ndubi, November 2002. 
The Importance of Social Capital in Colombian Rural Agro-Enterprises, by Nancy Johnson, Ruth Suarez, and Mark Lundy, November 2002.

27 Cooperation, Collective Action and Natural Resources Management in Burkina Faso: A Methodological Note, by Nancy McCarthy, Céline Dutilly-Diané, and Boureima Drabo, December 2002.

28 Understanding, Measuring and Utilizing Social Capital: Clarifying Concepts and Presenting a Field Application from India, by Anirudh Krishna, January 2003.

29 In Pursuit Of Comparable Concepts and Data, about Collective Action, by Amy Poteete And Elinor Ostrom, March 2003.

30 Methods of Consensus Building for Community Based Fisheries Management in Bangladesh and the Mekong Delta, by Parvin Sultana and Paul Thompson, May 2003.

31 Formal and Informal Systems in Support of Farmer Management of Agrobiodiversity: Some Policy Challenges to Consolidate Lessons Learned, by Marie Byström, March 2004.

32 What Do People Bring Into the Game: Experiments in the Field About Cooperation in the Commons, by Juan-Camilo Cárdenas and Elinor Ostrom, June 2004.

33 Methods for Studying Collective Action in Rural Development, by Ruth Meinzen-Dick, Monica Di Gregorio, and Nancy McCarthy, July 2004.

34 The Relationship between Collective Action and Intensification of Livestock Production: The Case of Northeastern Burkina Faso, by Nancy McCarthy, August 2004.

35 The Transformation of Property Rights in Kenya's Maasailand: Triggers and Motivations by Esther Mwangi, January 2005.

36 Farmers' Rights and Protection of Traditional Agricultural Knowledge, by Stephen B. Brush, January 2005.

37 Between Conservationism, Eco-Populism and Developmentalism - Discourses in Biodiversity Policy in Thailand and Indonesia, by Heidi Wittmer and Regina Birner, January 2005.

38 Collective Action for the Conservation of On-Farm Genetic Diversity in a Center of Crop Diversity: An Assessment of the Role of Traditional Farmers' Networks, by Lone B. Badstue, Mauricio R. Bellon, Julien Berthaud, Alejandro Ramírez, Dagoberto Flores, Xóchitl Juárez, and Fabiola Ramírez, May 2005.

39 Institutional Innovations Towards Gender Equity in Agrobiodiversity Management: Collective Action in Kerala, South India,, by Martina Aruna Padmanabhan, June 2005. 

and Biodiversity from Legal Pluralism, by Melanie G. Wiber, July 2005.

41 Who Knows, Who Cares? Determinants of Enactment, Awareness and Compliance with Community Natural Resource Management Bylaws in Uganda, by Ephraim Nkonya, John Pender, Edward Kato, Samuel Mugarura, and James Muwonge, August 2005.

42 Localizing Demand and Supply of Environmental Services: Interactions with Property Rights, Collective Action and the Welfare of the Poor, by Brent Swallow, Ruth MeinzenDick, and Meine von Noordjwik, September 2005.

43 Initiatives for Rural Development through Collective Action: The Case of Household Participation in Group Activities in the Highlands of Central Kenya, By Gatarwa Kariuki and Frank Place, September 2005.

44 Are There Customary Rights to Plants? An Inquiry among the Baganda (Uganda), with Special Attention to Gender, by Patricia L. Howard and Gorettie Nabanoga, October 2005.

45 On Protecting Farmers' New Varieties: New Approaches to Rights on Collective Innovations in Plant Genetic Resources by Rene Salazar, Niels P. Louwaars, and Bert Visser, January 2006.

46 Subdividing the Commons: The Politics of Property Rights Transformation in Kenya's Maasailand, by Esther Mwangi, January 2006.

47 Biting the Bullet: How to Secure Access to Drylands Resources for Multiple Users, by Esther Mwangi and Stephan Dohrn, January 2006.

48 Property Rights and the Management of Animal Genetic Resources, by Simon Anderson and Roberta Centonze, February 2006.

49 From the Conservation of Genetic Diversity to the Promotion of Quality Foodstuff: Can the French Model of 'Appellation d'Origine Contrôlée' be Exported? by Valérie Boisvert, April 2006.

50 Facilitating Collective Action and Enhancing Local Knowledge: A Herbal Medicine Case Study in Talaandig Communities, Philippines, by Herlina Hartanto and Cecil Valmores, April 2006.

51 Water, Women and Local Social Organization in the Western Kenya Highlands, by Elizabeth Were, Brent Swallow, and Jessica Roy, July 2006.

52 The Many Meanings of Collective Action: Lessons on Enhancing Gender Inclusion and Equity in Watershed Management, by Laura German, Hailemichael Taye, Sarah Charamila, Tesema Tolera, and Joseph Tanui, July 2006. 
53 Decentralization and Environmental Conservation: Gender Effects from Participation in Joint Forest Management, by Arun Agrawal, Gautam Yadama, Raul Andrade, and Ajoy Bhattacharya, July 2006.

54 Improving the Effectiveness of Collective Action: Sharing Experiences from Community Forestry in Nepal, by Krishna P. Achyara and Popular Gentle, July 2006.

55 Groups, Networks, and Social Capital in the Philippine Communities, by Marie Godquin and Agnes R. Quisumbing, October 2006.

56 Collective Action in Plant Genetic Resources Management: Gendered Rules of Reputation, Trust and Reciprocity in Kerala, India, by Martina Aruna Padmanabhan, October 2006.

57 Gender and Local Floodplain Management Institutions--A case study from Bangladesh, by Parvin Sultana and Paul Thompson, October 2006.

58 Gender Differences in Mobilization for Collective Action: Case Studies of Villages in Northern Nigeria, by Saratu Abdulwahid, October 2006.

59 Gender, Social Capital and Information Exchange in Rural Uganda, by Enid Katungi, Svetlana Edmeades, and Melinda Smale, October 2006.

60 Rural Institutions and Producer Organizations in Imperfect Markets: Experiences from Producer Marketing Groups in Semi-Arid Eastern Kenya, by Bekele Shiferaw, Gideon Obare and Geoffrey Muricho, November 2006.

61 Women's Collective Action and Sustainable Water Management: Case of SEWA's Water Campaign in Gujarat, India, by Smita Mishra Panda, October 2006.

62 Could Payments for Environmental Services Improve Rangeland Management inCentral Asia, West Asia and North Africa? by Celine Dutilly-Diane, Nancy McCarthy, Francis Turkelboom, Adriana Bruggeman, James Tiedemann, Kenneth Street and Gianluca Serra, January 2007.

63 Empowerment through Technology: Gender Dimensions of Social Capital Build-Up in Maharashtra, India, by Ravula Padmaja and Cynthia Bantilan, February 2007.

64 Gender and Collective Action: A Conceptual Framework for Analysis, by Lauren Pandolfelli, Ruth Meinzen-Dick, and Stephan Dohrn, May 2007.

65 Gender, Wealth, and Participation in Community Groups in Meru Central District, Kenya, by Kristin E. Davis and Martha Negash, May 2007.

66 Beyond Group Ranch Subdivision: Collective Action for Livestock Mobility, Ecological Viability, and Livelihoods, by Shauna BurnSilver and Esther Mwangi, June 2007. 
67 Farmer Organization, Collective Action and Market Access in Meso-America, by Jon Hellin, Mark Lundy, and Madelon Meijer, October 2007.

68 Collective Action for Innovation and Small Farmer Market Access: The Papa Andina Experience, by André Devaux, Claudio Velasco, Gastón López, Thomas Bernet, Miguel Ordinola, Hernán Pico, Graham Thiele, and Douglas Horton, October 2007.

69 Collective Action and Marketing of Underutilized Plant Species: The Case of Minor Millets in Kolli Hills, Tamil Nadu, India, by Guillaume P. Gruère, Latha Nagarajan, and E.D.I. Oliver King, M.S. Swaminathan Research Foundation, October 2007.

70 The Role of Public-Private Partnerships and Collective Action in Ensuring Smallholder Participation in High Value Fruit and Vegetable Supply Chains, by Clare Narrod, Devesh Roy, Julius Okello, Belem Avendaño, Karl Rich, and Amit Thorat, October 2007. 